\title{
DEVELOPING MAHI-TOI THEORY AND ANALYSIS
}

\author{
Jani Katarina Taituha Wilson*
}

\begin{abstract}
Many Māori researchers have mahi-toi skills. Mahi-toi, arts and the production of art, is where a concept takes physical form, and is brought into the physical realm by mahi-ā-ringa. The mahitoi practitioner is the conduit. When the practitioner is also the researcher and vice versa, these vernaculars can enrich each other, and structure the work. Setting research writing practice beside mahi-toi practice also lends theoretical and analytical frameworks that could be useful for mahitoi practitioners making the transition to academic research. In this article, I focus on mahi-toi as the scaffolding for theoretical analysis and writing frameworks across the arts. I demonstrate how I came to design the framework within the film theory context when it became apparent that post-colonial and Kaupapa Māori theories did not meet the needs of my research and analysis.
\end{abstract}

\section{Keywords}

mahi-toi, post-colonial theory, Kaupapa Māori theory, Te Kete Aronui, muka kete

\section{Introduction}

Writing and especially writing theory are very intimidating ideas for many indigenous students ... [and] many indigenous scholars who work in the social and other sciences struggle to write, theorize and research as indigenous scholars. (L. T. Smith, 2006, p. 29)
Linda Tuhiwai Smith's (2006) observation captures the ongoing tussles some emerging Māori scholars have with writing, theorising and researching. While Smith writes from a social sciences context, I contend this dilemma is not field-specific. Māori colleagues from across diverse scholarly disciplines and I often share our battles with the publication component of

* Ngāti Awa/Ngā Puhi/Ngāti Hine. Inaugural Māori Post-Doctoral Fellow, School of Art \& Design, Department of Creative Technologies, Auckland University of Technology, Auckland, New Zealand. Email: jani.wilson@aut.ac.nz

DOI: 10.20507/MAlJournal.2017.6.2.2 
our academic roles. A challenge for many of us, particularly new and emerging researchers, is how to transform the work from the oral format-in which we generally excel—into the academically written. Another matter is not tidily fitting within the boundaries of recognised theoretical domains. The reality is that we must write to belong to academia.

Māori researchers may have one or many mahi-toi skills. Mahi-toi, arts and the production of art, is where a concept takes physical form. The ideas are brought into the physical realm by mahi-ā-ringa, and the mahi-toi practitioner is the conduit. When the mahi-toi practitioner is also the researcher and vice versa, the vernaculars in both circles enrich and give structure to each other. Despite divergences in materials and technologies, when mahi-toi production processes are placed side by side, the parallels between them are unmistakable (Wilson, 2013). Setting the practice of writing beside mahi-toi practice also lends a structural, theoretical and analytical framework that with some development may be useful for both Māori researchers and mahi-toi practitioners making the transition to academic research and writing. Mahi-toi is a way of thinking through the process of transitioning from practice to theory and vice versa. This article explores mahi-toi as the potential scaffolding for a theoretical framework and a prospective writing structure for Māori scholars in the arts discipline. In the first section, I show how I came to design the Mahi-toi framework within a film theory context: existing theoretical frameworks did not correspond to my hapūspecific study, which consequently influenced my approach to film analysis. In the second section, I briefly unpack the pre-production, production and post-production phases of kete muka-flax-fibre basketry-to explicitly show how a mahi-toi framework can aid writing.

\section{Film analysis}

In its simplest of terms, film analysis is the examination of a film or its parts (Horrocks, 2004). Film analysis considers whatever is within the film's diegesis, the world constructed inside the film, and how it fits together (Hayward, 2000). Some film analysts concentrate on audience responses (Metz, 1974, 1977); others compare the filmmaker's intentions with the viewer's reading (Barthes, 1977). Māori film analysis is unique because of the distinctive Māori worldview it represents. A number of Māori scholars from various disciplines have contributed critical analyses of representations of Māori in New Zealand film (Hokowhitu, 2003, 2004, 2007, 2008; Mercier, 2007, 2010; Pihama, 1994, 1996, 2000, 2001; Walker, 2006; WalkerMorrison, 2011), particularly since Once Were Warriors (Tamahori, 1994). However, we see very few Māori in the schema of film studies (Barnes, 2011; Cruickshank, 2002; McDonnell, 1986, 1998; Wilson, 2006, 2013) and, consequently, very little Māori film analysis from within the discipline. With the recent successes of Māori-centred films, the New Zealand Film Commission will likely fund more projects featuring Māori within Māori contexts. Māori film analysis, particularly in relation to how tikanga, kawa, te reo and mātauranga Māori/-ā-iwi are represented on film, is increasingly significant because these pivotal aspects will potentially be displayed in ways requiring deeper thinking.

Film analyses through a kawa lens, for example, can look at the ways in which haukāinga are framed on their marae. During my doctoral research (Wilson, 2013), my Ngāi Taiwhakāea whānau viewed the short film Kerosene Creek (Bennett, 2002). Half of the film is set on an unnamed marae, where the hapu conducts the tangi of two young brothers. The viewing generated various hapū-specific questions, particularly in terms of the kawa on the film and the kawa on our marae. For instance, would Ngāi Taiwhakāea lower the flag for a film production? Would any of us climb inside a waka 
tūpāpaku or support such an act on our marae? Would our kahui kaumātua allow internal shots of our wharetipuna to add to a film's ambience? When hapū permit their marae to be part of a film production, where are the lines drawn between produced kawa and kawa tūturu? These are some of the important research questions that film analysis conducted via kawa can potentially generate for Aotearoa film studies in the future. Furthermore, such questioning opens up dialogue about the significance of and variances between hapū perceptions of Māoricentred films, and can facilitate a way forward for Māori filmmakers. Film analysis based on tikanga, kawa, te reo and mātauranga Māori/ -ā-iwi also distinguishes Māori film analysis from what film studies currently offers.

\section{Post-colonial theory}

During the initial stage of my doctoral research, it was assumed the work would fit into postcolonial theory, as Indigenous film scholarship had done for decades. The past-ness, however, of post-colonial generated obvious complications (L. T. Smith, 2006). Many Indigenous peoples are still affected by colonisation, which-for many of us-thwarts the post-ness of the theory. Despite this, post-colonial theory has led to some exceptionally provocative Indigenous screen scholarship (Chow, 1991, 1993, 1994, 2000; Hall, 1980a, 1980b, 1996a, 1996b; McClintock, 1992; Minh-Ha, 1989, 2014; Auode, 2004; Shaheen 2001; Shohat, 1992, 2006; Shohat \& Stam, 1994; Singh, 2001; Mishra, 1989; Mishra \& Hodge, 2008). Postcolonial theorist Edward Said (1993) borrowed contrapuntalism (also known as polyphony) from music, his creative outlet, and used it as a framework to analyse literature. Said was particularly well known for contrapuntal analyses of famous authors who denied Indigenous people presence in their native settings. The contrapuntal analyses exposed political and racial injustices by arranging the story's main narrative within the treble stave, and tabulated actual local historical affairs onto the bass stave. Using contrapuntalism to unpack the stories unambiguously forces a more critical and conscious re-reading of the works of celebrated authors who ignore racial injustices to Indigenous people.

As a Palestinian academic teaching in the United States, Said perhaps saw contrapuntalism as a way of reflecting the cultural contradictions he embodied. In contrast to Said's approach, the main aim of my examination was to construct a distinct hapū-centred analysis of Māori feature film characters in lead or support character roles. To draw out the distinct hapū-centred worldviews of my predominant hapū, I chose a monophonic view, as it best represented the distinct whānau/hapū voice, and because it kept the analysis contained within the hapū. The approach then veered sharply from polyphony. Mahi-toi analysis pivots on mātauranga-ā-iwi, tikanga and kawa. Mahi-toi invites all film scholars to present their specific hapū worldview, and to present questions, explore solutions and influence the analysis and outcome accordingly.

\section{Kaupapa Māori theory}

The second trajectory presented to my $\mathrm{PhD}$ was Kaupapa Māori theory (Kaupapa Māori). Kaupapa Māori draws critique, resistance, struggle and emancipation into a range of disciplines. Graham Smith (1997) proposes that Kaupapa Māori is where the theory and praxis of being Māori meet. It has influenced the methods through which Māori researchers conduct themselves among Māori in their professional capacity, and equally so in the direction and purpose of their research: in, for and by Māori. Angela Moewaka Barnes (2011) utilises Kaupapa Māori elements to structure her method of film analysis, and proffers a range of provocative examinations of pivotal Māoricentred films. Like all academic pathways, Kaupapa Māori has met with some resistance. In particular, Pākehā educationalist Elizabeth 
Rata (2003, 2004, 2005, 2006) contends that Kaupapa Māori has not received sufficient international testing for it to be considered "rigorous". Furthermore, she asserts that those who utilise Kaupapa Māori are a tribal "elite” (Rata, 2011a, 2011b, 2011c). Regardless, all interrogations directed at Kaupapa Māori contribute to its development, and to the development of Māori and Indigenous scholars who use it and attest to its saliency. Māori communities have been given voice through Kaupapa Māori research values, and its impacts can be seen across the disciplines. Kaupapa Māori has influenced education policy, research and governance. Fundamentally, Kaupapa Māori is a tūrangawaewae: a space where Māori scholars can satiate the rubrics of a discipline at the same time as they stand in the Màori communities they represent.

"Being Māori" is a central component of Kaupapa Māori (Pihama, 2001; G. H. Smith, 1997), and at face value appears simple. However, "being Māori” presented a number of challenges to my study. I will only sketch one here. Māori are not the same; some have been brought up in the whānau and hapū, speaking te reo, doing kapahaka, practising tikanga and kawa, and espousing/passing on important mātauranga-ā-iwi to tamariki/mokopuna. Others have not. But despite their estrangement, they cannot be excluded from identifying as Māori because they have whakapapa. The major challenge this presented to my research was that the analysis centred on the distinct Ngāi Taiwhakāea and Ngāti Kawa responses to Māori-centred films. The analysis was based on lived experience in the hapu, and how that empirically compared/contrasted with the cinematised āhua Māori. "Being Māori” then presented a complication to the distinct hapūcentred responses to the film selection. As my hapū were specific about presenting the hapū values in my study - in which they were invested participants_Kaupapa Māori was an obstacle to the kaupapa hapū, mainly because Kaupapa Māori does not speak to the uniqueness of Ngāi
Taiwhakāea and Ngāti Kawa views, our mita, kawa and tikanga. This meant that although Kaupapa Māori is acknowledged and important, it was not a featured tool of analysis.

\section{Te Kete Aronui}

Te Kete Aronui underpins Mahi-toi film analysis. As film is an art, Mahi-toi-as I will show-emerged as a more suitable structure. It is believed Tānemahuta climbed 12 heavens to retrieve three kete containing the world's knowledge. Te Kete Aronui contains the arts, peace and the senses (Best, 1995; Fraser, 2009; Moorfield, 2005; Morrison, 1999). Timoti Kāretu's (2008) definition is particularly salient:

It is the kete of the intellectual and the philosopher ... and philosophers of the Māori world were the equal of poets and philosophers anywhere.... The body of writing and language is being added to constantly with new compositions of haka, waiata, waiata$\bar{a}$-ringa and poi as well as short stories, the odd novel and play, and articles on various topics. (p. 88)

Here Kāretu pinpoints the space where "Māori intellectuals" are equally as creative as they are academic, and vice versa. Te Kete Aronui is where mahi-toi are transmitted from the conceptual world, through the hands, and into the physical world; literally where theory and art meet and culminate in a tangible and beautiful end product. Te Kete Aronui opens out academia for those who engage in mahi-toi, and encourages them to bring their skills and vernacular to academia. Academia can equally lend to the various mahi-toi in turn.

Kathie Irwin (1992) said that "real power lies with those who design the tools" (p. 5), and that we can build them ourselves. As I have illustrated, and continue to demonstrate in the following section, Māori have deep, beautiful and ancient theories that are easily discernible in our traditional arts. As emerging Māori 
scholars, we are often expected to conform to the frameworks available to satiate the academy. But challenging the parameters of widely accepted theories is an unconventional activity, particularly in disciplines where Māori are underrepresented. To challenge is not to discredit. To contest what is available means the discipline is in constant development and evolution. Ultimately, we want to fit the discipline, but on our terms.

\section{Lending the art practice structures to academic writing}

To this point, I have outlined why it was necessary to conceptualise a specific theoretical trajectory for my own research in film studies, a discipline heavily reliant on theory and practice. As a practitioner in a number of arts, and a new and emerging academic, I had an epiphany, which I will outline here. During kapahaka, raranga and waiata composition, I am fastidious, devoted and engaged. In kapahaka, for example, every toe point, head-flick, placement of the patu and note are deliberate. What was I giving to kapahaka that I was not imparting to the writing, upon which my place in academia pivots? I was not translating the meticulousness, self-editing, self-criticism and care taken in my arts practice into writing.

Whether it be in static, moving image or performance, mahi-toi have strict, labour-intensive processes that consist of pre-production, production and post-production phases. Through unpacking the artistic processes, I contend that thinking through them is as useful in academic research and writing environments as it is in the production of art. Utilising this framework, I have managed to structure and direct my work more meaningfully. Fundamentally though, it helps me to think about film/media/ performance/arts via a three-pronged, threedimensional production phase.

\section{Kete muka}

The previous section was devoted to showing how I came to think of Mahi-toi. Utilising kete muka as an example, this section shows how Mahi-toi works. Here, I sketch a framework that has sustained the kete muka process, arguably for millennia. This section is neither complete, nor a "how to" guide. It is intended to briefly articulate the complexity and intricacy of kete muka, to show the logic and precision within traditional mahi-toi processes and practices, an extremely useful skill kairaranga can transfer into the process of writing.

Fundamentally, all mahi-toi hinge on wairua. Master weaver Erenora Puketapu-Hetet (1989) asserted that weaving is

[a] time to give thanks to Tānemahuta for the material whose life-force has been given another dimension so that it lives again in another form, to give pleasure and usefulness to humankind ... The weaver normally experiences feelings of being linked with something greater than herself and the present ... [s/he] begins to understand why weaving is more than learning manual skills. (p. 2)

Here, Puketapu-Hetet explains that weaving is bending and entwining the fruits of Tānemahuta, breathing him into a different, practical shape. Although remodelled, his mauri is present in the art, and thus, raranga-and all of the traditional Māori arts-is of the spiritual paradigm. Kairaranga are human conduits between the conceptual, spiritual and physical worlds. When considered in this way, it is understandable that in traditional times, specific karakia were aimed at the womb of wāhine in the hopes of conceiving a weaver. Post-natally, tohi rituals were performed over infants, and the gods were implored to endow the child with weaving qualities (Mead, 1999). It is clear then, that raranga is beyond the practice and taonga it produces, and pivots on wairua. 


\section{Mahi-toi pre-production}

- Theme

- Conceptualisation

- Visualisation

- Planning (timing etc.)

- Resources

- Material preparation

\section{THEME}

The pre-weaving phase consists of conceptualisation and visualisation. Both rely on a theme that determines the overall completed look, the colour scheme and the context within which the piece is produced. The theme considers the purpose of the kete, who will receive it and why.

\section{CONCEPTUALISATION}

Raranga is intensely mathematical, geometrical and symmetrical, as are many other forms of mahi-toi. With the theme and concept in mind, kairaranga count out how many aho, whenu and blades of harakeke are required. They also consider the tree that will provide the appropriate dye, and the use of embellishments such as tassels, feathers or tāniko. The kōrero as to why certain feathers are attached are critical to kete muka. Research ensures that the kairaranga does not whati. The research may focus on finer details such as the feathers of birds that may be considered tapu to the receiver's people, or a negative tohu, and thus inappropriate. When tāniko bands are attached, particular shapes, mostly chevrons, triangles and diamonds, may also not be appropriate for the receiver.

\section{VISUALISATION}

Kairaranga think of the kete in its completed form. There are a range of whatu options, and they must decide which will be utilised in the body of the kete, and if or where embellishments may be attached. Symmetrical forms are balanced in appearance to show the weaver's dexterity and tension control across the work.
The visualisation stage is when the kairaranga plots the piece out line by line, and considers the necessary number of whatu.

\section{PLANNING}

Raranga draws on environmental, botanical and cultivation knowledge, and requires a keen eye on the māramataka. Kete muka pivots on the correct plant, and the cultivation of pa harakeke can take a year or more. Veteran kairaranga sometimes have their own pā, while others access public cultivations. Regardless, they make note of the best time to draw from them, and the time that is best to leave the pa to replenish itself. They make mental note of where and when the harakeke can be sourced, to ensure they have access to quality muka year around. Alternatively, they prepare sufficient muka for future projects during the high season. With the harakeke calendar in mind, kairaranga think in reverse from the finished kete, back through the production and pre-production phases, and sets small tasks and milestones. They are realistic about the completion time.

\section{RESOURCES}

When collecting harakeke, special karakia and mihi are invoked to Tānemahuta to acknowledge his contribution, presence and wairua (Puketapu-Hetet, 1989). Karakia is crucial when feathers are collected from a fallen bird. The wairua component is fundamental during the collection of resources. There are tikanga, but these are generally common-sense. One example is when using the maripi, cuts are made left to right, away from the rito, to ensure the longevity of the plant and the continuity of the raranga practice (Clarke \& McCreanor, 2006; Rokx, 1997). Another instance of tikanga is that menstruating wāhine are not to weave, but advances in feminine hygiene eliminate the potential contamination of the muka. Whether to observe these tikanga is completely reliant on the interpretation/perception of one's kaiako. 


\section{MATERIAL PREPARATION}

The blades of harakeke are divided into two down the vertebrae, which are kept aside. A small incision is made on the dull underside of the leaf with a mussel shell (or other implement). The shell is then used to scrape the epidermis from the harakeke, exposing the muka. The kairaranga clumps together an appropriate number of fibres (approximately 20 for whenu and five for aho) and completes the miro process, rolling the fibres downwards from the thigh to the knee, and back and forth a number of times, until the muka resembles long, platinum blonde cords. The whenu are arranged into bunches of 10, and are washed, dried and prepared for weaving proper.

\section{Pre-writing}

What learnings are in the kete muka pre-weaving stage that can be transferred to the pre-writing phase of academic writing? Like pre-weaving, pre-writing should closely consider the theme, concept, and headings and subheadings. The points each section will potentially make should be visualised prior to the research proper. Planning, and in particular timing, ought to be considered realistically so the draft will be completed according to the publishing organisation's schedule. For example, planning an article could be as uncomplicated as dividing the sections of a 5,000-word article into smaller parts such as:

- Introduction $=500$ words

- Section 1 = 500 words

- 2 subsections (A) -500 words $=1,000$ words

- Section $2=500$ words

- 2 subsections (B) -500 words $=1,000$ words

- Section $3=500$ words

- Conclusion $=500$ words

- Bibliography

Essentially, this example divides a daunting writing assignment into smaller, achievable tasks, just as weavers would plan their whatu for each line, subsection and section, within the scheme of the wider project. To keep the pre-writing phase simple, one primary resource is closely considered, and one secondary for counterpoint. Any further resources are embellishments to show further reading. Immediately prior to writing, all of the resources are stripped of the highlighted points from the primary and secondary resources, and they are arranged into the headings and subheadings. These are marked on the schedule to ensure the first draft follows the co-ordinates set in the initial plan. However, it is most important to karakia or to have as much quiet and thoughtful time as writing time, to keep one's mind and thinking clear.

\section{Mahi-toi production}

- Do

- Review/revisit concept

- Edit/re-edit

- Complete

DO

Weaving proper takes less time than the preparation phase, but it takes physical, mental and spiritual stamina. One by one, every whenu is meticulously secured by a pair of aho. The top pair is replaced by the bottom pair, and vice versa, securing the whenu in place. The first aho woven across all of the whenu creates the spine that is placed over a wooden "T" apparatus to keep it straight. A straightforward whatu will result in a very tidy and conservative look. To give a textured look, weavers may do crossovers, or create hourglass-like shapes via a miss-andreplace pattern, but this is at their discretion. Whatu is repeated until the intended kete size and overall look are achieved. The embellishments such as feathers, tassels and tāniko are fixed in place as it is woven. Tension across the kete must be consistent to ensure there are no bulges or missed stitches. Consistent tension is fundamental to the raranga canon. 


\section{REVIEW/REVISIT CONCEPT}

As the kete takes shape, clear decision-making about the style of weave, and where the embellishments sit in the scheme of the kete, becomes apparent. Reviewing and re-visiting the original concept and purpose of the kete is critical, as doing so avoids the undesirable unpicking process.

\section{EDIT}

Kairaranga are particularly fastidious about their mahi-toi, and in pursuit of precision and accuracy, they have sharp, fanatical eyes for detail. Such meticulousness is most necessary for the line-by-line editing required for kete muka. Experience means they are able to easily identify inaccuracies at first glance.

\section{COMPLETE}

Tapiki is the last weaving phase, and is when the edges are turned inward to make a tidy edge and are cast off. Two tuapuku or tāwai cords are plaited, and attached to the kete as kiwai. The kiwwai transforms the piece from static art into a practical, mobile item to appeal to the eye and to be used.

\section{Writing}

As in weaving, one must do the writing. According to the plan, write the entire section or subsection, mistakes and all. Unlike kete muka, writing errors can be unpicked and neatened with relative ease, but are often not clearly recognised until they appear on the page. Add "embellishments" (supplementary readings) if necessary, but leave them out if they will detract from the co-ordinates in the original plan. Move on, continuing the pattern until the body text is complete. Print the first draft comprising all sections except the introduction and conclusion. Edit, particularly the parts that are superfluous, to ensure the main research points are discussed thoroughly, and the theme is the constant and obvious through line.

\section{Mahi-toi post-production}

- Last looks

- Release

- Debrief

\section{LAST LOOKS}

During post-production, it is most important to tidy up the loose ends, clipping the overhanging muka to cancel out interference when the kete is in use. Above all, there are specific tikanga such as mihi and karakia that accompany the completion of a kete to protect the kairaranga, the receiver and the plant, all interconnected with Tānemahuta by the kete. The kōrero accompanying the kete puts the receiver, the occasion and the piece into context. Ideally, these are carried with the kete through every uri it is passed to.

\section{RELEASE}

Releasing the kete muka and kōrero to the receiver can be both gratifying and terrifying. This moment is an opportunity to see the recipient's response to the taonga, to share the piece's mauri and to receive feedback. This phase is often a relief.

\section{DEBRIEF}

Ultimately, kairaranga are their own worst critics. Each kete muka is an opportunity to take learnings into the next kete project. This could be as practical as plotting out timing better or remembering where a tree is located (for the bark), or the location of a pā harakeke for a future project.

There is much more to kete muka than I have lightly sketched here. Despite the brevity though, it is easily identifiable how complex, intricate and detailed the kete muka process is. These are the very important transferable aspects that are key to successful academic writing. 
POST-WRITING

Like the release stage during the post-weaving phase of kete muka, finalise by writing the introduction and conclusion, and tying/tidying up the loose ends. Edit meticulously until there is flow when read aloud. Once the edits are complete, invite an objective other to read it, and according to the other's trusted recommendations, make one last edit. Release the article to the potential publishers and await feedback. Make their recommended amendments. Celebrate your accomplishment while making mental note of how the journey through the next potential article will be improved through the learnings not possible without the mistakes in this piece. Here is a time for pause and reflection on the kaupapa and spirit of the work prior to beginning the next one.

\section{Conclusion: Mahi-toi potential}

Like academic research and writing, mahitoi such as kete muka are intense, laborious practices that are heavily reliant on research, patience, clarity of mind and physical endurance. Mahi-toi practitioners are privy to procedures and rituals, and the structure of the practice is a considerably important component. The kete muka overview displayed the imperative of using simple language, as though cartographing readers through a mahi-toi practice for the first time. At the same time, the sketch of kete muka aimed to proffer insights into te ao Māori. In this article, I have outlined two important learnings that can be transferred from mahi-toi to Māori arts research. The first is the need to connect with Te Kete Aronui, to breathe a concept to life, and to produce and analyse the piece using the three-pronged, three-dimensional production-phase format. The second learning is to use one's chosen mahi-toi as the basis of a robust, systematic writing structure.

This twofold article has only explored the potential of Mahi-toi. The advancement of Mahi-toi relies on critical feed-forward by
Māori arts scholars or researchers who may argue, debate, consider or apply it. Critique, questioning and rigorous testing are important components of developing Mahi-toi as a potential trajectory for creative people entering research, and vice versa. Using the metaphor of the kete muka process, the harakeke has been collected, stripped and rolled into whenu. The whenu are now circulated out to the scholars who, like me, have found it necessary to consider theoretical and structural tools from mātauranga Māori that better suit and/ or appeal or may be more relevant to Māori. Moving Mahi-toi forward, each response, a pair of aho, fastens the whenu together, and determines the shape, hue and size of the kete as a collective effort.

\section{Acknowledgements}

I acknowledge Rangimāria Te Kanawa-Davis for generously teaching her raranga expertise in the Edgecumbe/Patutātahi community as a volunteer for decades, and for her patience, guidance and aroha. She and her whānaulike mine-are currently refugees from the Edgecumbe Flood. Ka tuku tāku aroha ki à koutou i te wā tino pouri. Ahakoa, he iti noa, he pounamu, he tohu aroha. This article was generously supported by the Māori/Pacific postdoctoral fellowship in the School of Art \& Design at AUT.

\section{Glossary}

$\begin{array}{ll}\begin{array}{l}\text { aho } \\ \text { àhua }\end{array} & \begin{array}{l}\text { weft, cross threads } \\ \text { shape, appearance, } \\ \text { condition, character, } \\ \text { personality } \\ \text { traditional Māori posture } \\ \text { haka }\end{array} \\ & \text { dance } \\ \text { hapū } & \text { flax } \\ \text { harakeke } & \text { local people of the marae } \\ \text { haukāinga } & \end{array}$




\begin{tabular}{|c|c|c|c|}
\hline kahui kaumātua & group of elders & raranga & to weave or plait \\
\hline kaiako & teacher, tutor & rito & centre shoot part of a flax \\
\hline kairaranga & weaver/s & & plant \\
\hline kapahaka & a group performing haka & tamariki & children \\
\hline karakia & $\begin{array}{l}\text { incantation, ritual chant, } \\
\text { prayer }\end{array}$ & Tānemahuta & $\begin{array}{l}\text { god of the forest, trees and } \\
\text { birds }\end{array}$ \\
\hline kaupapa & $\begin{array}{l}\text { topic, matter for discussion, } \\
\text { plan, purpose }\end{array}$ & tangi & $\begin{array}{l}\text { to cry or mourn, mourning } \\
\text { rituals }\end{array}$ \\
\hline kawa & $\begin{array}{l}\text { customs and protocols of the } \\
\text { marae }\end{array}$ & $\begin{array}{l}\text { tāniko } \\
\text { taonga }\end{array}$ & $\begin{array}{l}\text { fine finger weaving } \\
\text { treasured belonging }\end{array}$ \\
\hline kete & basket, kit & tapiki & to cast or lock off in weaving \\
\hline kete muka & flax-fibre basket or kit & tapu & be sacred, prohibited \\
\hline kīwai & handle & tāwai & two-stranded plait \\
\hline kōrero & $\begin{array}{l}\text { story, talk, discussion, } \\
\text { dialogue }\end{array}$ & te reo & $\begin{array}{l}\text { the voice or language } \\
\text { of Indigenous New }\end{array}$ \\
\hline mahi-ā-ringa & work done with the hands & & Zealanders \\
\hline mahi-toi & $\begin{array}{l}\text { art or craft and their } \\
\text { production }\end{array}$ & $\begin{array}{l}\text { tikanga } \\
\text { tohi }\end{array}$ & $\begin{array}{l}\text { customs, correct procedures } \\
\text { to perform a ritual ceremony }\end{array}$ \\
\hline māramataka & Māori calendar & & over a child \\
\hline marae & tribal meeting grounds & tohu & sign \\
\hline maripi & cutting implement, knife & tuapuku & four-stranded plait \\
\hline mātauranga & $\begin{array}{l}\text { knowledge, understanding, } \\
\text { wisdom }\end{array}$ & $\begin{array}{l}\text { tūpāpaku } \\
\text { tūrangawaewae }\end{array}$ & $\begin{array}{l}\text { corpse } \\
\text { standing place, the place }\end{array}$ \\
\hline $\begin{array}{l}\text { mātauranga-ā- } \\
\text { iwi }\end{array}$ & $\begin{array}{l}\text { knowledge exchanged among } \\
\text { the iwi }\end{array}$ & tūturu & $\begin{array}{l}\text { where one belongs } \\
\text { true, authentic }\end{array}$ \\
\hline mātauranga & knowledge learned across & uri & descendant \\
\hline Māori & Māori & wāhine & women \\
\hline mauri & $\begin{array}{l}\text { life essence, life force, energy, } \\
\text { life principle }\end{array}$ & $\begin{array}{l}\text { waiata } \\
\text { waiata-ā-ringa }\end{array}$ & $\begin{array}{l}\text { sing or song } \\
\text { action song }\end{array}$ \\
\hline mihi & $\begin{array}{l}\text { speech of greeting, } \\
\text { acknowledgement, tribute }\end{array}$ & $\begin{array}{l}\text { wairua } \\
\text { waka tūpāpaku }\end{array}$ & $\begin{array}{l}\text { soul or spirit } \\
\text { burial chest, coffin, canoe for }\end{array}$ \\
\hline miro & to spin, twirl or twist twine & & a corpse \\
\hline mita & dialect & whakapapa & continuous layering of \\
\hline mokopuna & to be a grandchild & & generations, genealogy \\
\hline muka & $\begin{array}{l}\text { fibres extracted from certain } \\
\text { types of harakeke }\end{array}$ & whānau & $\begin{array}{l}\text { to be born or give birth, } \\
\text { family }\end{array}$ \\
\hline pā harakeke & flax bush & wharetipuna & ancestral house \\
\hline $\begin{array}{l}\text { Pākehā } \\
\text { patu }\end{array}$ & $\begin{array}{l}\text { Caucasian New Zealander } \\
\text { club-like weapon }\end{array}$ & whati & $\begin{array}{l}\text { break or make an error/ } \\
\text { mistake }\end{array}$ \\
\hline poi & $\begin{array}{l}\text { a light ball on the end of a } \\
\text { cord, swung, twirled, and } \\
\text { flicked on wrists }\end{array}$ & $\begin{array}{l}\text { whatu } \\
\text { whenu }\end{array}$ & $\begin{array}{l}\text { to weave } \\
\text { a strand or warp of flax }\end{array}$ \\
\hline
\end{tabular}




\section{References}

Aoude, I. (2004). Arab Americans and the criminalization of dissent. In B. Kapferer (Ed.), The World Trade Center and global crisis: Critical perspectives (pp. 46-51). New York, NY: Berghahn Books.

Austen, J. (1814). Mansfield Park. London, England: T. Egerton. http://doi.org/cctp

Barnes, A. M. (2011). Ngā para i te kabikātoa: Māori filmmaking, forging a path (Unpublished $\mathrm{PhD}$ thesis). University of Auckland, New Zealand.

Barthes, R. (1977). The death of the author (S. Heath, Trans.). In R. Barthes (Ed.), Image music text (pp. 142-148). New York, NY: Hill and Wang.

Bennett, M. (Dir.). (2002). Kerosene Creek. New Zealand: Blueskin Films.

Best, E. (1995). The pa Mãori. Wellington, New Zealand: Te Papa Tongarewa Museum of New Zealand.

Chow, R. (1991). Woman and Chinese modernity: The politics of reading between West and East. Minneapolis, MN: University of Minnesota Press.

Chow, R. (1993). Writing diaspora: Tactics of intervention in contemporary cultural studies. Bloomington, IN: Indiana University Press.

Chow, R. (1994). Where have all the natives gone? In A. Bammer (Ed.), Displacements: Cultural identities in question (pp. 125-151). Bloomington, IN: Indiana University Press.

Chow, R. (2000). Modern Chinese literary and cultural studies in the age of theory: Reimagining a field. Durham, NC: Duke University Press. http://doi. org/cctq

Clarke, E., \& McCreanor, T. (2006). He wahine tangi tikapa . . .: Statutory investigative processes and the grieving of Maori families who have lost a baby to SIDS. Kōtuitui: New Zealand Journal of Social Sciences Online, 1(1), 25-43.

Cruickshank, S. G. (2002). From a scary black bastard: Some thoughts from a post-graduate Maori film student (Unpublished master's thesis).University of Auckland, New Zealand.

Fraser, T. N. (2009). Māori-Tuboe epistemology: Stages of sustaining tribal identity through Tuhoe performing arts (PhD thesis, University of British Columbia, Vancouver, Canada). Retrieved from https:/circle.ubc.ca/bitstream/ handle/2429/13902/ubc_2009_fall_fraser_tina. pd f? sequence $=1$

Hall, S. (1980a). Cultural studies: Two paradigms. In T. R. Young (Ed.), Media, culture and society (pp. 57-73). Fort Collins, CO: Colorado State University.

Hall, S. (1980b). Encoding/decoding. In S. Hall (Ed.), Culture, media, language (pp. 128-138). London, England: Hutchinson.

Hall, S. (1996a). Introduction: Who needs "identity"? In S. Hall \& P. Du Gay (Eds.), Questions of cultural identity (pp. 1-17). London, England: Sage.

Hall, S. (1996b). When was the "post-colonial"? Thinking at the limit. In I. Chambers \& L. Curtis (Eds.), The post-colonial question: Common skies, divided horizons (pp. 242-260). London, England: Routledge.

Hayward, S. (2000). Key concepts in cinema studies (2nd ed.). London, England: Routledge.

Hokowhitu, B. (2003). Māori masculinity, post-structuralism, and the emerging self. New Zealand Sociology Journal, 18(2), 179-201.

Hokowhitu, B. (2004). Tackling Māori masculinity: A colonial genealogy of savagery and sport. The Contemporary Pacific, 16(2), 259-284. http:// doi.org/fpt78n

Hokowhitu, B. (2007). Understanding Whangara: Whale Rider as simulacrum. New Journal of Media Studies, 10(2), 53-70. http://doi.org/cctr

Hokowhitu, B. (2008). The death of Koro Paka: "Traditional" Māori patriarchy. The Contemporary Pacific, 20(1), 115-141. http:// doi.org/fw7shg

Horrocks, R. (2004). Why study media production? In L. Goode \& N. Zuberi (Eds.), Media studies in Aotearoa/New Zealand (pp. 18-31). Albany, New Zealand: Pearson Education New Zealand.

Irwin, K. (1992). Towards theories of Māori feminisms. In R. Du Plessis (Ed.), Feminists'voices: Women's studies texts for Aotearoa New Zealand (pp. 5-18). Oxford, England: Oxford University Press.

Kāretu, T. (2008). Te kete tuawhā, te kete aronui-The fourth basket. Te Kaharoa, 1(1), 86-99. http:// doi.org/cc97

McClintock, A. (1992). The angel of progress: Pitfalls of the term "post-colonialism". Social Text, Third World and Post-Colonial Issues, 31/32, 84-98. http://doi.org/drdc3f

McDonnell, B. (1986). The translation of New Zealand fiction into film (Unpublished PhD thesis). University of Auckland, New Zealand.

McDonnell, B. (1998). All virgin soil and it don't belong to no one? Notes on the representation of nineteenth century New Zealand feature films. New Zealand Journal of Media Studies, 4(2), 16-25. 
Mead, H. M. (1999). Te whatu tāniko: Tāniko weaving-technique and tradition (Rev. ed.). Auckland, New Zealand: Reed.

Mercier, O. (2007). Close encounters of the Māori kind: Talking interaction in the films of Taika Waititi. New Zealand Journal of Media Studies, 10(2), 37-51. http://doi.org/ccts

Mercier, O. (2010). "Welcome to my interesting world": Pōwhiri styled encounter in Boy. Illusions, no. 42, 3-7.

Metz, C. (1974). Film language: A semiotics of cinema (M. Taylor, Trans.). New York, NY: Oxford University Press.

Metz, C. (1977). The imaginary signifier: Psychoanalysis and the cinema (C. Britton, A. Williams, B. Brewster \& A. Guzzetti, Trans.). Bloomington, IN: Indiana University Press.

Minh-ha, T. T. (1989). Woman, native, other. Bloomington, IN: Indiana University Press.

Minh-Ha, T. T. (2014). When the moon waxes red: Representation, gender and cultural politics. London, England: Routledge.

Mishra, V. (1989). The centre cannot hold: Bailey, Indian culture and the sublime. South Asia, 12(1), 103-114. http://doi.org/crj7v2

Mishra, V., \& Hodge, B. (2008). What is post(-) colonialism? Textual Practice, 5(3), 399-414. http://doi.org/dtddfr

Moorfield, J. C. (2005). Te aka Māori-English, English-Māori dictionary and index. Retrieved from http://www.maoridictionary.co.nz

Morrison, A. (1999). Space for Maori in tertiary institutions: Exploring two sites at the University of Auckland (Unpublished master's thesis). University of Auckland, New Zealand.

Pihama, L. (1994). Are films dangerous? A Maori woman's perspective on The Piano. Hecate, 20(2), 239-242.

Pihama, L. (1996). Repositioning Maori representation: Contextualising Once Were Warriors. In J. Dennis \& J. Bieringa (Eds.), Film in Aotearoa New Zealand (pp. 191-193). Wellington, New Zealand: Victoria University Press.

Pihama, L. (2000). Ebony and ivory: Constructions of Maori in The Piano. In H. Margolis (Ed.), Jane Campion's The Piano (pp. 114-134). New York, NY: Cambridge University Press.

Pihama, L. (2001, April). From Once Were Warriors to carrying The Piano: The decontextualisation of Māori image in film. Paper presented at the American Education Research Association Conference, Seattle, Washington.
Pihama, L. (2001). Tìhei mauri ora. Honouring our voices: Mana wabine as a kaupapa Māori theoretical framework (Unpublished $\mathrm{PhD}$ thesis). University of Auckland, New Zealand.

Puketapu-Hetet, E. (1989). Māori weaving. Auckland, New Zealand: Pitman.

Rata, E. (2003). Late capitalism and ethnic revivalism: A “new middle age”?'. Anthropological Theory, 3(1), 46-64. http://doi.org/d6xq8q

Rata, E. (2004, September). Under achievement in Māori education: Why kaupapa Māori can't help. Paper presented at the Politics of Early Childhood Education Symposium, Auckland, New Zealand.

Rata, E. (2005). Rethinking biculturalism. Anthropological Theory, 5(3), 267-284. http:// doi.org/fshs6p

Rata, E. (2006). The political strategies of ethnic and indigenous elites. In E. Rata \& R. Openshaw (Eds.), Public policy and ethnicity: The politics of ethnic boundary making (pp. 40-55). Houndmills, England: Palgrave Macmillan.

Rata, E. (2011a). Discursive strategies of the Maori tribal elite. Critique of Anthropology, 31(4), 359-380.

Rata, E. (2011b). The politics of knowledge in education. British Educational Research Journal, 38(1), 103-124. http://doi.org/dn9x55

Rata, E. (2011c). Theoretical claims and empirical evidence in Maori education discourse. Educational Philosophy and Theory, 44(10), 1060-1072. http://doi.org/bj7gbv

Rokx, H. (1997). Manaakihia te pa harakekeNurturing the family: A Maori woman's story. Childrenz Issues: Journal of the Children's Issues Centre, 1(2), 17-20.

Said, E. (1993). Culture and imperialism. London, England: Chatto \& Windus.

Shaheen, J. (2001). Reel bad Arabs: How Hollywood vilifies a people. New York, NY: Olive Branch Press.

Shohat, E. (1992). Taboo memories: Diasporic voices. Durham, NC: Duke University Press.

Shohat, E. (2006). Notes on the post-colonial. Social/ Text, 31/32, 99-113. http://doi.org/cctt

Shohat, E., \& Stam, R. (1994). Unthinking Eurocentrism: Multiculturalism and the media. London, England: Routledge.

Singh, N. G. K. (2001). The mirror and the Sikh: The transformation of Ondaatje's Kip. In C. Shackle, G. Singh, \& A. Mandair (Eds.), Sikh religion, culture and ethnicity (pp. 118-141). Richmond, England: Curzon. 
Smith, G. H. (1997). The development of kaupapa Maori: Theory and praxis (Unpublished $\mathrm{PhD}$ thesis). University of Auckland, New Zealand.

Smith, L. T. (2006). Decolonizing methodologies: Research and Indigenous peoples. London, England: Zed Books.

Tamahori, L. (Dir.). (1994). Once were warriors. New Zealand: Communicado Productions.

Walker, D. (2006). Representing the self, representing the other: Ethics and ethnicity in the contemporary cinema of Aotearoa. International Yearbook of Aesthetics, 10, 104-131.
Walker-Morrison, D. (2011). Souls of the warriors: Once Were Warriors in France. Te Kaharoa, $1(1), 18-33$.

Wilson, J. K. T. (2006). The cinematic economy of Cliff Curtis (Unpublished master's thesis). University of Auckland, New Zealand.

Wilson, J. K. T. (2013). Whiripapa: Tāniko, whānau and kōrero-based film analysis (Unpublished $\mathrm{PhD}$ thesis). University of Auckland, New Zealand. 